\title{
Physiological potential and health of peanut seed treated with ozone
}

\section{Potencial fisiológico e sanidade de sementes de amendoim submetidas a ozonização}

\author{
Izamara Marzolla Gutierres Jacob Machado; Luiz Henrique Inacio; Nátaly Diane \\ Rocha Silva2; Francisco José Teixeira Gonçalves ${ }^{3}$; Denis Santiago Costa ${ }^{4 *}$
}

\begin{abstract}
Highlights
Peanut cultivars are different in seed health and physiology.

Ozone gas does not affect germination in peanut seeds at the rate studied.

Ozone gas alters seed length according to the peanut cultivars at the rate studied.

Ozone gas does not eradicate/control fungi in peanut seeds at the rate studied.

Ozone gas alters Rhizopus incidence according to the peanut cultivars.
\end{abstract}

\begin{abstract}
Peanut seed can be infected by pathogen diseases that adversely affect the oil crop's value chain. Ozone gas $\left(\mathrm{O}_{3}\right)$ can be an alternative for the control of fungal diseases due to its high oxidizing potential. In this study, we investigated the effects of $\mathrm{O} 3$ exposure time on physiological and health characteristics of seed from three peanut cultivars. Seed from peanut cultivars Granoleico, IAC OL3, and IAC 503 were analyzed for their health (blotter test) and physiological potential (germination, first count, and seedling length) after exposure to $\mathrm{O}_{3}$ for $0,1,8$, and $16 \mathrm{~h}$. Peanut seed physiological quality and health differed among cultivars. Exposure of seed from peanut cultivars IAC OL3, IAC 503, and Granoleico to $\mathrm{O}_{3}$ at a rate of $600 \mathrm{mg} \mathrm{h}^{-1}$ did not affect the development of normal seedlings as measured by the first count and germination, but seedling length increased, decreased, or was not affected in cultivars Granoleico, IAC 503, and IAC OL3, respectively. Also, $\mathrm{O}_{3}$ did not eradicate fungal infections in peanut seed treated with $\mathrm{O}_{3}$ at a rate of $600 \mathrm{mg}$ $\mathrm{h}^{-1}$ for up to $16 \mathrm{~h}$, but the incidence of the fungus Rhizopus sp. in seed from cultivars IAC OL3, Granoleico, and IAC 503 increased, decreased or was not affected, respectively, after $8 \mathrm{~h}$.
\end{abstract}

Key words: Arachis hypogaea L. Fungi. Germination. Ozone.

1 Agronomy Undergraduate Students, Instituto Federal de Mato Grosso do Sul, IFMS, Nova Andradina, MS, Brazil. E-mail: izagutierres@gmail.com; luizhenriqueinacio@hotmail.com

2 Agronomist at Ciarama Máquinas, Nova Andradina, MS, Brazil. E-mail: natalydiany@hotmail.com

3 Prof. DSc. at Instituto Federal do Maranhão, IFMA, Codó, MA, Brazil. E-mail: jose.teixeira@ifma.edu.br

4 Prof. DSc. at IFMS, Nova Andradina, MS, Brazil. E-mail: denis.costa@ifms.edu.br

* Author for correspondence

Received: June 12, 2021 - Approved: Nov. 22, 2021 


\section{Resumo}

Sementes de amendoim são alvos de patógenos e geram problemas à cadeia produtiva da espécie oleaginosa. Uma alternativa de controle de microrganismos é a aplicação da ozonização devido seu alto potencial de oxidação. Portanto, o objetivo deste ensaio foi avaliar a aplicação do gás ozônio, em três cultivares de amendoim, nos atributos fisiológicos e sanitários de acordo com diferentes períodos de exposição das sementes ao $\mathrm{O}_{3}$. Neste ensaio, sementes de amendoim dos cultivares Granoloeico, IAC OL3 e IAC 503 foram analisadas quanto a sanidade (blotter test) e potencial fisiológico (germinação, primeira contagem e comprimento de plântulas) após submissão ao gás ozônio por 0, 1, 8 e 16 horas. De acordo com os cultivares, sementes de amendoim apresentam diferentes desempenhos fisiológicos e sanitários de qualidade. A exposição de sementes dos cultivares de amendoim IAC OL3, IAC 503 e Granoleico ao gás ozônio até 16 horas na taxa de 600 mg/h não interfere na formação de plântulas normais avaliada na primeira contagem de germinação e na germinação, entretanto há efeitos de incremento, decréscimo ou nulo no comprimento de plântulas para os cultivares Granoleico, IAC 503 e IAC OL3, respectivamente. Não há erradicação de fungos presentes em sementes de amendoim expostas ao gás ozônio numa taxa de $600 \mathrm{mg} / \mathrm{h}$ até 16 horas, porém a incidência do fungo Rhizopus sp. aumenta, diminui ou é indiferente no período de 8h para os cultivares IAC OL3, Granoleico e IAC 503, respectivamente.

Palavras-chave: Arachis hypogaea L. Fungos. Germinação. Ozônio.

\section{Introduction}

\section{Peanut (Arachis hypogaea L.), a} member of the legume family Fabaceae native to South America and an economically important crop in several countries, is grown mainly for its edible seed, which are rich in vitamins and nutrients, have high oil (49.66\%) and protein $(24.35 \%)$ content, and can be processed and used as an animal feed or as human food in the form of peanut butter, salted nuts, and snacks (Bonku \& Ju, 2019). In addition to these uses, the oil extracted from the seed can be used for biodiesel production as an alternative to other vegetable oils such as soybean, sunflower, coconut, palm, rapeseed, and cotton (Shalmashi \& Khodadadi, 2018).

China is the largest producer of peanuts worldwide holding an estimated $38 \%$ of global production. Even though Brazil accounts for approximately only $1.2 \%$ of the world total, the crop has a large economic impact on the agriculture sector, mainly because of its contribution to sugarcane field renovation (Food and Agriculture Organization of the United Nations [FAO], 2021; D. F. L. Santos et al., 2019). According to Ferrari, Costa and Castro (2012), there are two peanut growing seasons in Brazil: the first, higher-yield crop is planted between October and November during the sugarcane off-season to enhance the renovation of sugarcane fields through biological nitrogen fixation (BNF), reducing implementation costs of the new sugarcane field, and a second, lower-yield crop planted from February to March.

In new peanut fields, seed are among the most expensive inputs and make up a large proportion of production costs because of their low quality, while the crop can also be affected by many disease problems (Farinelli, Horita, \& Santos, 2018). In a previous study from Barbosa, Homem and Tarsitano (2014), the contribution of seed to peanut production 
costs has been historically high because large quantities are needed to overcome the problems associated with low physiological potential (germination and vigor) and achieve the initial stand expected for each cultivar. Consistent with this information, F. Santos, Medina, Lourenção, Parisi and Godoy (2013) reported that, in the state of São Paulo, seed lots whose quality fell below marketable standards were a common occurrence that was attributable to the presence of fungi and insects.

Several fungus species such as Penicillium sp., Fusarium sp., Aspergillus sp., Cladosporium sp., Epicoccum sp., Phoma sp., and Rhizopus sp. are commonly found infecting peanut seed (Barrozo et al., 2012; F. Santos et al., 2013) and among these, some like Aspergillus niger and Fusarium oxysporum may cause pre- and post-emergence damping-off, resulting in direct damage to the crop (Bellettini, Endo, Miglioranza, \& Santiago, 2005).

Previous authors investigated the chemical treatment of seed with fungicides for reducing the incidence of fungi in peanut seed and even though fungicide application the fungal infections from the seed was not eliminated but they observed a reduction in fungal incidence and an increase in seed germination and vigor (F. Santos, Medina, Lourenção, Parisi, \& Godoy, 2016a).

Chemical seed treatments have been extensively used in agriculture however, the search for new tools to improve seed health and reduce the incidence of pathogenic microorganisms has been crucial to the success of the agricultural value chain.

Ozone $\left(\mathrm{O}_{3}\right)$ is a gas molecule formed naturally in the atmosphere having a high oxidizing potential. Thus, $\mathrm{O}_{3}$ has been used as a promising tool for reducing the incidence of some pathogenic microorganisms, but results depend on the gas concentration, the exposure time, and the type of microorganism (Silva, Luvielmo, Geyer, \& Prá, 2011). In seed, $\mathrm{O}_{3}$ has been used experimentally and shown potential in reducing the incidence of microorganisms, as observed for Aspergillus sp. and Penicillium sp. in sunflower (Rodrigues et al., 2015) and rice (R. R. Santos, Faroni, Cecon, Ferreira, \& Pereira, 2016b). In peanut, studies have focused on the effects of $\mathrm{O}_{3}$ on the quality of grain (lipid and protein content) and in reducing the effects of aflatoxins (Alencar, Faroni, Soares, Carvalho, \& Pereira, 2011; Sahab, Hassanien, El-Nemr, Abdel-Alim, \& Abdel-Wahhab, 2013) but not in seed vigor or healthy.

Therefore, in this study, we investigated the effects of $\mathrm{O}_{3}$ exposure time on physiological and healthy characteristics of seed from three peanut cultivars.

\section{Materials and Methods}

Seed source, seed moisture content, and fungal identification

Peanut seed from cultivars IAC OL3, Granoleico, and IAC 503 were harvested in the 2017-2018 crop year at the experimental farm of the Federal Institute of Mato Grosso do Sul (IFMS), Nova Andradina Campus (2204'58.3" S, 5328'09.4" W; 346.5 m a.s.l) in Nova Andradina, state of Mato Grosso do Sul, central-west Brazil. Seed were harvested, field dried, manually shelled, and stored in a refrigerator at $10^{\circ} \mathrm{C}$ and $50 \%$ relative humidity for five months until the experiment. 
One week before the experiment, the seed were removed from the refrigerator and allowed to sit at room temperature to reach the equilibrium moisture content. Next, seed moisture content was determined by weight (i.e., wet - dry weight) from two samples weighing $4.5 \pm 0.5 \mathrm{~g}$ each using the oven method at $105 \pm 3{ }^{\circ} \mathrm{C}$. Seed were oven dried for $24 \mathrm{~h}$ and results were expressed on a percent wet basis, according to the Rules for Seed Testing documented by Ministério da Agricultura, Pecuária e Abastecimento [MAPA] (2009).

To characterize peanut cultivars with respect to the incidence of fungi, a seed health test was conducted using the blotter test method described by MAPA (2009). Briefly, 10 peanut seed were evenly distributed on filter paper moistened with demineralized distilled water until its weight was 2.5 times that of its dry weight and placed into transparent glass Petri dishes $(\mathrm{d}=9.5 \mathrm{~cm})$, totaling 400 seed per cultivar. Next, the dishes were stored in a growth chamber at $20{ }^{\circ} \mathrm{C}$ for seven days with photoperiod set at $12 \mathrm{~h}$. Seed were then examined individually under a stereoscopic microscope at $3 \times$ and $8 \times$ magnification for the presence of fungal structures with results expressed as percent incidence. Fungal identification was performed based on morphological characteristics including color, size, fructification, and structures as described by Barnett and Hunter (1998). In cases where the fungus could not be identified visually, it was streaked on agar plates containing potato, carrot and agar (PCA) medium for sporulation and identification under a light optical microscope. Results for seed health are expressed as percent incidence as shown in Table 1.

Table 1

Moisture content and fungal incidence in seed from three peanut cultivars produced in Nova Andradina, MS, Brazil

\begin{tabular}{|c|c|c|c|c|c|c|}
\hline Cultivar & $\begin{array}{l}\text { Seed moisture } \\
\text { content }\end{array}$ & $\begin{array}{l}\text { Fusarium } \\
\text { sp. }\end{array}$ & $\begin{array}{l}\text { Penicillium } \\
\text { sp. }\end{array}$ & $\begin{array}{c}\text { Aspergillus } \\
\text { sp. }\end{array}$ & $\begin{array}{l}\text { Rhizopus } \\
\text { sp. }\end{array}$ & $\begin{array}{l}\text { Lasiodiplodia } \\
\text { sp. }\end{array}$ \\
\hline & $\ldots(\%) \ldots$ & \multicolumn{5}{|c|}{$\ldots$} \\
\hline IAC 503 & 5.7 & 5.0 & 7.25 & 8.75 & 1.25 & 0.0 \\
\hline Granoleico & 6.0 & 5.5 & 0.5 & 4.0 & 2.25 & 0.0 \\
\hline IAC OL3 & 6.0 & 17.5 & 0.75 & 8.25 & 10.0 & 1.75 \\
\hline
\end{tabular}

Experimental design and $\mathrm{O}_{3}$ treatments

After fungal identification, an $\mathrm{O}_{3}$ exposure trial was conducted as $3 \times 4$ factorial scheme with three peanut cultivars and four $\mathrm{O}_{3}$ exposure times replicated four times with 400 seed.
For $\mathrm{O}_{3}$ application, seed samples were wrapped in tulle fabric and placed inside a 15-L closed plastic box adapted for gas circulation through a cooler. $\mathrm{O}_{3}$ was produced and released using an ozone generator at a rate of $600 \mathrm{mg} \mathrm{h}^{-1}$ for $0,1,8$, and $16 \mathrm{~h}$. 


\section{Physiological potential assessment}

A germination test, first count, and seedling length measurements were performed to estimate seed physiological potential. The germination test was conducted according to the Rules for Seed Testing published by MAPA (2009), with four replicates of 50 seeds per treatment (sampling unit). Seed from each treatment were placed with tweezers on filter paper (germitest) soaked to 2.5 times its dry weight with demineralized distilled water and prepared as rolled paper (RP). Seed were germinated in a growth chamber at $25^{\circ} \mathrm{C}$ for 10 days, when seed and seedlings were classified as described by MAPA (2009). The first count was performed five days after incubation, when all seedlings that had all the essential structures developed were counted. Results for the germination test and first count were expressed as percent normal seedlings.

Seedling length measurements were taken from four replicates of 20 seeds (arranged in two 10-seeds rows with the hilum facing down) per treatment, similarly to the germination test. After seven days, the length of normal seedlings was measured in $\mathrm{cm}$ with a ruler, as described by Nakagawa (1999). Results were expressed as $\mathrm{cm}_{\text {seedling }}{ }^{-1}$.

\section{Seed health assessment}

To determine the effects of $\mathrm{O}_{3}$ treatments on seed health, samples exposed to $\mathrm{O}_{3}$ were evaluated using the blotter test as described above and analyzed as a $3 \times 4$ factorial arranged in a randomized complete block design. Seed health results were expressed as percent fungal incidence.

\section{Statistical analysis}

Data were checked for normality and homogeneity of variance and a $\sqrt{x+1}$ transformation was applied when necessary to meet the assumptions of the model, followed by the $\mathrm{F}$ test at the 0.05 probability level. Cultivar mean values were compared by Tukey's test at the 0.05 probability level and $\mathrm{O}_{3}$ exposure times were analyzed using polynomial regression in Sisvar software.

\section{Results and Discussion}

The $F$ test revealed that percent germination and first count were significantly different between cultivars, but not between $\mathrm{O}_{3}$ exposure times (Table 2). Germination and first count were not statistically different between cultivars Granoleico and IAC 503, but were significantly higher than in cultivar IAC OL3. 


\section{Table 2}

Physiological characteristics of seed from peanut cultivars IAC OL3, Granoleico, and IAC 503 as influenced by $\mathrm{O}_{3}$ exposure time

\begin{tabular}{|c|c|c|c|}
\hline Source & $\begin{array}{l}\text { Germination } \\
(\%)\end{array}$ & $\begin{array}{c}\text { First germination count } \\
(\%)\end{array}$ & $\begin{array}{l}\text { Seedling length } \\
\text { (cm seedling }^{-1} \text { ) }\end{array}$ \\
\hline & \multicolumn{3}{|c|}{ 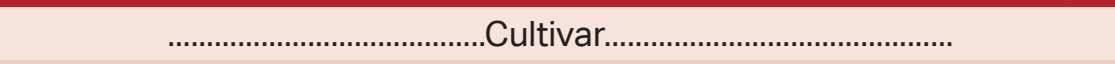 } \\
\hline IAC OL3 & $75 b$ & $71 \mathrm{~b}$ & $11.0 \mathrm{~b}$ \\
\hline Granoleico & $93 a$ & $91 \mathrm{a}$ & $11.17 b$ \\
\hline \multirow[t]{2}{*}{ IAC 503} & $93 \mathrm{a}$ & $86 a$ & $14.83 \mathrm{a}$ \\
\hline & \multicolumn{3}{|c|}{ 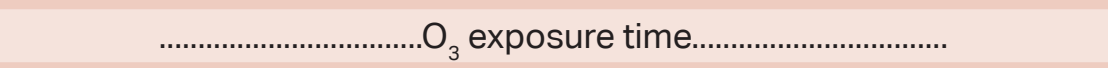 } \\
\hline $\mathrm{Oh}$ & 84 & 80 & 12.77 \\
\hline $1 \mathrm{~h}$ & 88 & 83 & 14.07 \\
\hline $8 \mathrm{~h}$ & 88 & 84 & 11.08 \\
\hline $16 \mathrm{~h}$ & 88 & 84 & 11.39 \\
\hline Prob.>F cult. & $0.000^{* *}$ & $0.000^{* *}$ & $0.000^{* *}$ \\
\hline Prob.>F time & $0.586^{\text {n.s }}$ & $0.428^{\text {n.s }}$ & $0.004^{* *}$ \\
\hline Prob.>F cult. $\times$ time & $0.418^{\mathrm{n} . \mathrm{s}}$ & $0.157^{n . s}$ & $0.000^{* *}$ \\
\hline Overall average & 87 & 83 & 12.33 \\
\hline Coef. Var. (\%) & 7.32 & 8.29 & 16.8 \\
\hline
\end{tabular}

n.s. Non-significant; ** significance at the 0.01 probability level. Mean values followed by the same letter in a column are not significantly different by the $\mathrm{F}$ test at the 0.05 probability level.

There was a significant interaction of seedling length with cultivar and $\mathrm{O}_{3}$ exposure time (Table 2) and data for cultivars IAC 503 and Granoleico were fit to polynomial equations, but the relationship between seedling length and $\mathrm{O}_{3}$ exposure was not significant for cultivar IAC OL3. Data for cultivar Granoleico were best fit to an increasing linear function with positive slope, $\mathrm{R}^{2}=0.5632$, and overall equation $y=0.23 x+9.68$, indicating that seedling length increased with increasing $\mathrm{O}_{3}$ exposure. Conversely, data for cultivar IAC 503 were best fit to a decreasing linear function with negative slope, $\mathrm{R}^{2}=0.9711$, and overall equation $y=-0.58 x+18.5$, indicating that seedling length decreased as $\mathrm{O}_{3}$ exposure increased (Figure 1).

Ozone treatments have a high oxidizing potential and because they are not selective to fungi only may also cause damage to seed. $\mathrm{No} \mathrm{O}_{3}$-induced damage to seed was observed in the germination test or first count, which is explained by the fact that any potential degradation of cell membrane caused by $\mathrm{O}_{3}$ (Silva et al., 2011) is not measured by either test. However, for seed vigor as measured by seedling length, three different results were observed for the three peanut cultivars, indicating that responses to $\mathrm{O}_{3}$ are mediated by inherent characteristics of each cultivar. 


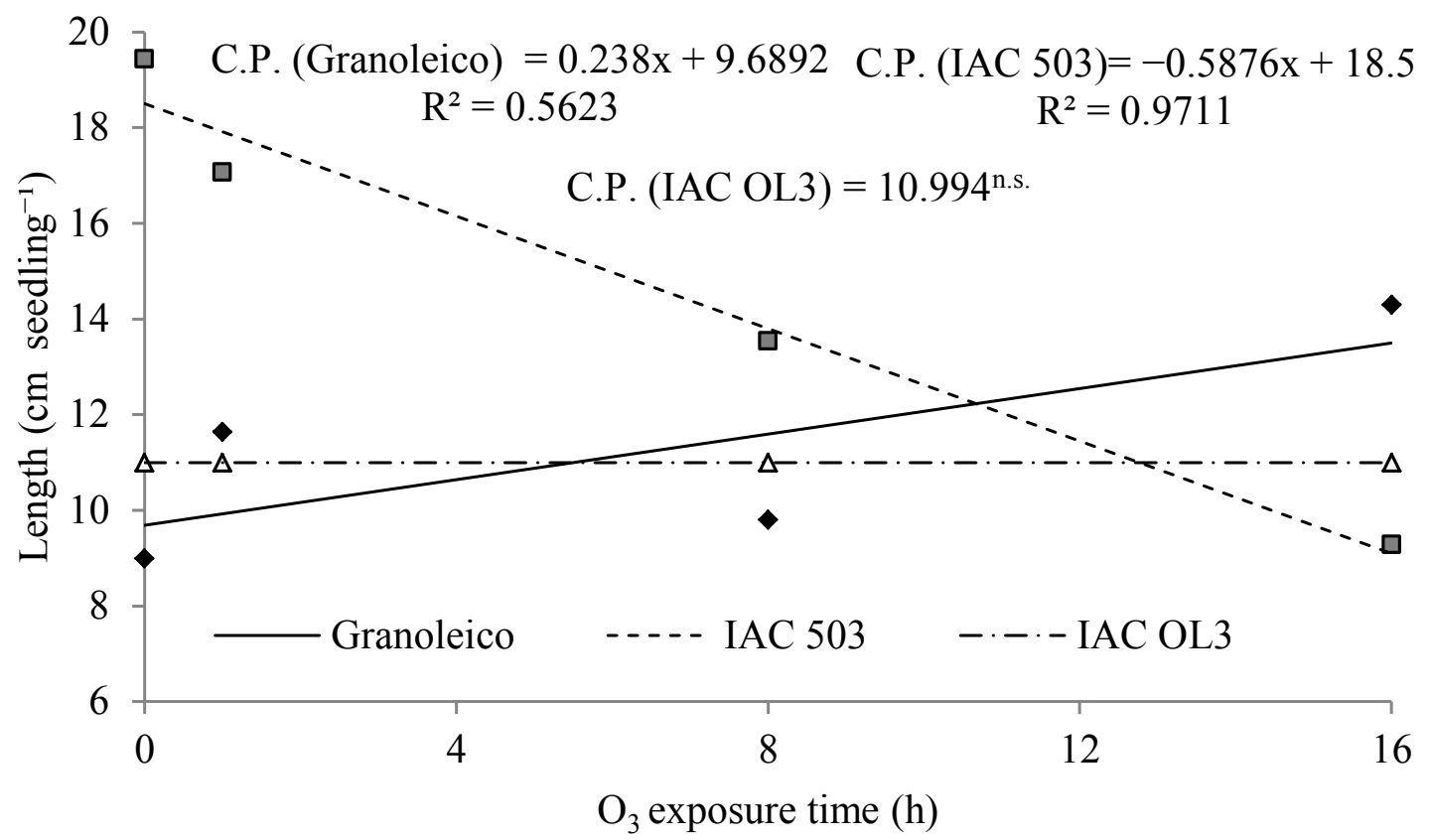

Figure 1. Interaction of $\mathrm{O}_{3}$ exposure time with seedling length in seed from peanut cultivars IAC OL3, Granoleico, and IAC 503.

Treatment effects of $\mathrm{O}_{3}$ on seed physiological quality have also been investigated in other crops. A previous study evaluated the physiological quality of maize seed soaked in ozonated water at a concentration of up to $30 \mathrm{mg} \mathrm{L}^{-1}$ for 120 min and observed no differences in the physiological potential of seed (Maximiano, Carmona, Souza, Alencar, \& Blum, 2018). In wheat, authors found no differences in primary root elongation of seed treated with $\mathrm{O}_{3}$, but observed changes in root and shoot length (Lazukin et al., 2018). Conversely, in sunflower, whose chemical composition is more similar to that of peanut, authors observed that $\mathrm{O}_{3}$ administered in seed for $60 \mathrm{~min}$ at $1741 \mathrm{ppmv}$ and $0.24 \mathrm{~g} \mathrm{~h}^{-1}$ increased the number of normal seedlings at the end of the germination test (Rodrigues et al., 2015).
The following fungi were identified infecting peanutseed: Fusariumsp., Penicillium sp., Aspergillus sp., Rhizopus sp., Lasiodiplodia sp., and Pythium sp. (Table 3). Results of the coefficient of variation for fungal incidence between cultivars for each fungus species analyzed individually were high and an arcsine transformation was applied. High coefficients of variation are typically observed in health data for peanut because they consist of count data that are expressed as a percentage, as was also observed by Grigoleto, Medina, Parisi and Santos (2019) and F. Santos et al. (2016a).

Treatment effects of $\mathrm{O}_{3}$ exposure were not statistically significant for fungal incidence when data for each fungus species were analyzed individually (except for Rhizopus sp., which showed a significant interaction), but there were significant differences between 
the cultivars. Cultivar IAC OL3 showed the highest percent incidence for Fusarium sp., Aspergillus sp., Rhizopus sp., and Pythium sp. and the lowest incidence for Penicillium sp. together with cultivar Granoleico. In contrast, cultivar IAC 503 had the highest percent incidence for Penicillium sp. and the lowest incidence for Rhizopus sp., and differences in the incidence of the fungus Lasiodiplodia sp. were not statistically significant between the cultivars. As for the interaction between fungal incidence and $\mathrm{O}_{3}$ exposure time, data for Rhizopus sp. were best fit to decreasing and increasing quadratic polynomial functions for cultivars Granoleico $\left(0.07 x^{2}-1.226 x+8.25\right.$; $\left.\mathrm{R}^{2}=0.961\right)$ and IAC OL3 $\left(-0.17 \mathrm{x}^{2}+2.559 \mathrm{x}+\right.$ 9.28; $\left.R^{2}=0.951\right)$, respectively, indicating that the incidence of the fungus decreased in the former and increased in the latter cultivar when seeds were exposed to $\mathrm{O}_{3}$ for up to $8 \mathrm{~h}$ (Figure 2).

Table 3

Fungal incidence in seed from peanut cultivars IAC OL3, Granoleico, and IAC 503 as influenced by $\mathrm{O}_{3}$ exposure time

\begin{tabular}{|c|c|c|c|c|c|c|}
\hline Source & $\begin{array}{l}\text { Fusarium } \\
\text { sp. }\end{array}$ & $\begin{array}{l}\text { Penicillium } \\
\text { sp. }\end{array}$ & $\begin{array}{c}\text { Aspergillus } \\
\text { sp. }\end{array}$ & $\begin{array}{c}\text { Rhizopus } \\
\text { sp. }\end{array}$ & $\begin{array}{l}\text { Lasiodiplodia } \\
\text { sp. }\end{array}$ & $\begin{array}{l}\text { Pythium } \\
\text { sp. }\end{array}$ \\
\hline \multicolumn{7}{|c|}{ 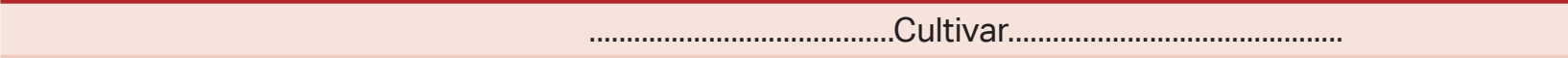 } \\
\hline IAC OL3 & $9.31 \mathrm{a}$ & $1.44 \mathrm{~b}$ & 19.38 a & $11.62 \mathrm{a}$ & $0.75 a$ & $0.25 a$ \\
\hline Granoleico & $2.43 \mathrm{~b}$ & $0.69 \mathrm{~b}$ & $2.56 \mathrm{~b}$ & $6.43 \mathrm{~b}$ & $0.25 \mathrm{a}$ & $\mathrm{Ob}$ \\
\hline \multirow[t]{2}{*}{ IAC 503} & $2.31 \mathrm{~b}$ & $8.25 \mathrm{a}$ & $6.44 b$ & $0.25 \mathrm{c}$ & $0.31 \mathrm{a}$ & $\mathrm{Ob}$ \\
\hline & \multicolumn{6}{|c|}{ 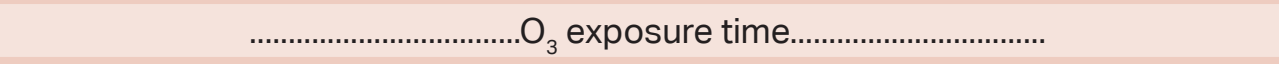 } \\
\hline $\mathrm{Oh}$ & 4.41 & 2.83 & 9.42 & 5.58 & 0.5 & 0.16 \\
\hline $1 \mathrm{~h}$ & 5.08 & 2.5 & 8.92 & 6.58 & 0.33 & 0.16 \\
\hline $8 \mathrm{~h}$ & 4.41 & 4.0 & 9.42 & 7.41 & 0.41 & 0.0 \\
\hline $16 \mathrm{~h}$ & 4.83 & 4.5 & 10.08 & 4.83 & 0.5 & 0.0 \\
\hline Prob.>F cult. & $0.0^{* *}$ & $0.00^{* *}$ & $0.00^{* *}$ & $0.0^{* *}$ & $0.0981^{\text {n.s }}$ & $0.0^{* *}$ \\
\hline Prob.>F time & $0.8657^{n . s}$ & $0.4677^{\text {n.s }}$ & $0.924^{\text {n.s }}$ & $0.18^{\text {n.s }}$ & $0.923^{\text {n.s }}$ & $0.1314^{n . s}$ \\
\hline Prob. $>F$ cult. $\times$ time & $0.1478^{n . s}$ & $0.1478^{n . s}$ & $0.1387^{\text {n.s }}$ & $0.0^{* *}$ & $0.2504^{\mathrm{n} . \mathrm{s}}$ & $0.0913^{n . s}$ \\
\hline Overall average & 4.68 & 3.46 & 9.46 & 6.1 & 0.44 & 0.08 \\
\hline C.V. (\%) & 49.3 & 101.89 & 44.12 & 48.98 & 158.22 & 282.84 \\
\hline Trans. C.V. (\%) & 21.49 & 31.68 & 19.69 & 2.4 & 21.83 & 9.44 \\
\hline
\end{tabular}




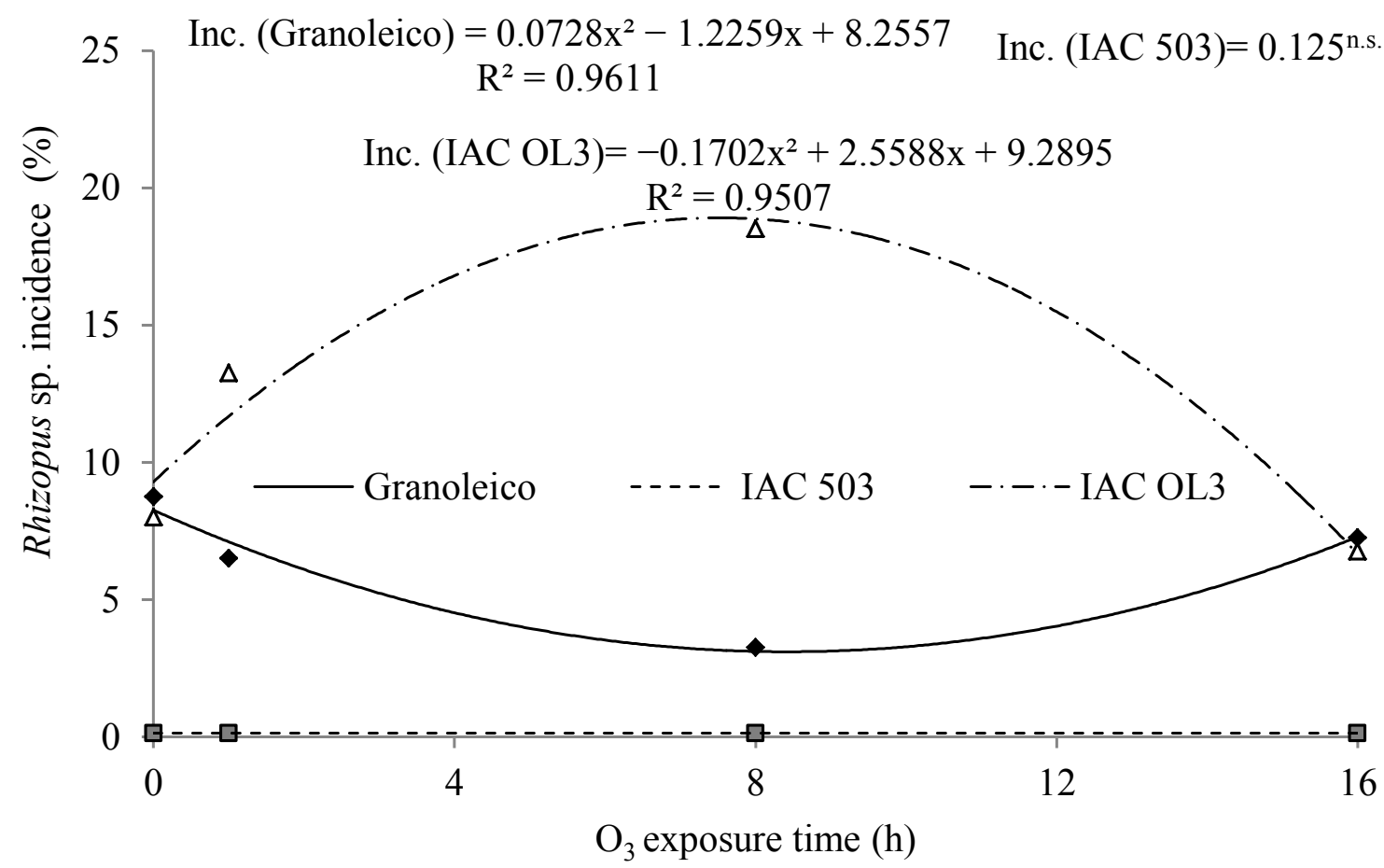

Figure 2. Interaction of $\mathrm{O}_{3}$ exposure time with the incidence of Rhizopus sp. in seed from peanut cultivars IAC OL3, Granoleico, and IAC 503.

Fungal infections in peanut seed are a common occurrence during storage, and there is a very close relationship between seed health and physiological quality (Begum, Venudevan, \& Jayanthi, 2013; F. Santos et al., 2016a). As seen in the current study, fungal incidence can vary depending on the cultivar genetics, which explains the results observed for each fungus species. As for the $\mathrm{O}_{3}$ treatments, their inability to control/ eradicate the fungi indicates that further studies with longer exposure times or higher gas concentrations are needed for effective seed pathogen control.

In other crops, results of $\mathrm{O}_{3}$ treatments in the control of seed pathogens have been mixed. In maize, a study shows that $\mathrm{O}_{3}$ preconditioning was not effective in the control of Fusarium sp. in artificially inoculated seed that were soaked in ozonated water (Maximiano et al., 2018). Conversely, Marique, Allard and Spanoghe (2012) have used an ozone generator at $2 \mathrm{~g} \mathrm{~h}^{-1}$ and observed a reduction in the incidence of Fusarium sp. in wheat seed treated with $\mathrm{O}_{3}$ for 8,10 , and 12 min. The authors also reported that increasing the exposure time to 10 min reduced seed germination. Reductions in the incidence of Aspergillus sp. and Penicillium sp. in sunflower seed treated with $\mathrm{O}_{3}$ at a concentration of 1741 ppmv $\left(0.24 \mathrm{~g} \mathrm{~h}^{-1}\right)$ for $60 \mathrm{~min}$ were also observed by Rodrigues et al. (2015).

The differences observed in this study suggest that intrinsic characteristics of each cultivar lead to different physiological and health responses to $\mathrm{O}_{3}$. Ozone treatment as a seed treatment technique warrants further investigation in peanut and other crops given 
its potential as a viable alternative for the control of fungi population in seeds.

\section{Conclusion}

Exposure of seed from peanut cultivars IAC OL3, IAC 503, and Granoleico to $\mathrm{O}_{3}$ for up to $16 \mathrm{~h}$ at a rate of $600 \mathrm{mg} \mathrm{h}^{-1}$ did not affect the development of normal seedlings as measured by the first count and germination test, but seedling length increased, decreased, or was not affected in cultivars Granoleico, IAC 503, and IAC OL3, respectively. Also, $\mathrm{O}_{3}$ did not control fungal infections in peanut seed treated with $\mathrm{O}_{3}$ at a rate of $600 \mathrm{mg} \mathrm{h}^{-1}$ for up to $16 \mathrm{~h}$, but the incidence of the fungus Rhizopus $\mathrm{sp}$. in seed from cultivars IAC OL3, Granoleico, and IAC 503 increased, decreased, or was not affected, respectively, after $8 \mathrm{~h}$.

\section{Acknowledgements}

The authors thank Cooperativa Agroindustrial (COPLANA) for providing seeds of the three peanut cultivars. We also acknowledge the National Council for Scientific and Technological Development (CNPq) for a scientific and technological initiation grant to the first three authors.

\section{References}

Alencar, E. R., Faroni, L. R. D., Soares, N. F. F., Carvalho, M. C. S., \& Pereira, K. F. (2011). Effect of the ozonization process on the quality of peanuts and crude oil. Revista Brasileira de Engenharia Agrícola e Ambiental, 15(2), 154-160. doi: 10.1590/ S1415-43662011000200009
Barbosa, R. M., Homem, B. F. M., \& Tarsitano, M. A. A. (2014). Custo de produção e lucratividade da cultura do amendoim no município de Jaboticabal, São Paulo. Ceres, 61(4), 475-481. doi: 10.1590/0034737X201461040005

Barnett, H. L., \& Hunter, B. B. (1998). Illustrated genera of imperfect Fungi. St. Paul: The American Phytopathological Society.

Barrozo, L. M., Alves, E. U., Gomes, D. P., Silva, K. B., Paz, D. S., \& Vieira, D. L. (2012). Qualidade sanitária de sementes de Arachis hypogaea L. em função de velocidades de arranquio e recolhimento. Bioscince Journal, 28(4), 573-579. Recuperado de http://www.seer.ufu.br/ index.php/biosciencejournal/article/ view/13657/9747

Begum, M. A. J., Venudevan, B., \& Jayanthi, M. (2013). Storage fungi in groundnut and assicuate seed quality deterioration - a review. Plant Pathology Journal, 12(3), 127-134. doi: 10.3923/ppj.2013.127.134

Bellettini, N. M. T., Endo, R. M., Miglioranza, E., \& Santiago, D. C. (2005) Patogenicidade de fungos associados as sementes de amendoim cv. Tatu. Semina: Ciências Agrárias, 26(2), 167-172. doi: 10.5433/ 1679-0359.2005v26n2p167

Bonku, R., \& Yu, J. (2019) Health aspects of peanuts as an outcome of its chemical composition. Food Science and Human Wellness, 9(1), 21-30. doi: 10.1016/j. fshw.2019.12.005

Farinelli, J. B. M., Horita, K., \& Santos, D. F. (2018). Analysis of the economic viability of the peanut crop in the region of Jaboticabal, São Paulo. Científica, 46(3), 215-220. doi: 10.15361/1984-5529.2018v46n3p215220 
Ferrari, J., Neto, Costa, C. H. M., \& Castro, G. S. A. (2012). Ecofisiologia do amendoim. Scientia Agraria Paranaensis, 11(4), 1-13. doi: 10.18188/sap.v11i4.6033

Food and Agriculture Organization of the United Nations (2021). Faostat statistical database. Roma: FAO. Retrieved from http://www.fao.org/faostat/en/\#data/QC/ visualize

Grigoleto, M. R. P., Medina, P. F., Parisi, J. J. D., \& Santos, F. (2019). Health aspects and ideal temperature for germination of peanut seeds. Journal of Seed Science, 41(2), 233-243. doi: 10.1590/2317-1545v41n2 195483

Lazukin, A., Serdukov, Y., Pinchuk, M., Stepanova, O., Krivov, S., \& Lyubushkina, I. (2018). Treatment of spring wheat seeds by ozone generated from humid air and dry oxygen. Research in Agricultural Engineering, 64(1), 34-40. doi: 10.17221/106/2016-rae

Marique, T., Allard, O., \& Spanoghe, M. (2012). Use of self-organizing map to analyze images of fungi colonies grown from Triticum aestivum seeds disinfected by ozone treatment. International Journal of Microbiology, 2012, 865175. doi: 10. $1155 / 2012 / 865175$

Maximiano, C. V., Carmona, R., Souza, N. O. S., Alencar, E. R., \& Blum, L. E. B. (2018) Physiological and sanitary quality of maize seeds preconditioned in ozonated water. Revista Brasileira de Engenharia Agrícola e Ambiental, 22(5), 360-365. doi: 10.1590/1807-1929/agriambi.v22n5 p360-365.

Ministério da Agricultura, Pecuária e Abastecimento (2009). Regras para análise de sementes. Brasília: MAPA/ ACS. Recuperado de https://www.gov.br/ agricultura/pt-br/assuntos/laboratorios/ arquivos-publicacoes-laboratorio/ regras-para-analise-de-sementes.pdf

Nakagawa, J. (1999). Testes de vigor baseados no desempenho de plântulas. In F. C. Krzyzanowski, R. D. Vieira, \& J. B. FrançaNeto (Eds.), Vigor de sementes: conceitos e testes (cap. 2, pp. 1-24). Londrina: Abrates.

Rodrigues, V. O., Costa, F. R., Nery, M. C., Cruz, S. M., Melo, S. G. F., \& Carvalho, M. L. M. (2015). Treating sunflower seeds subjected to ozonization. Journal of Seed Science, 37(3), 202-210. doi: 10.1590/2317-1545 v37n3148582

Sahab, A. F., Hassanien, F. R., El-Nemr, S. R., Abdel-Alim, H. A., \& Abdel-Wahhab, M. A. (2013). Effect of ozone gaseous on aflatoxin degradation and fat and protein content in peanut seeds. Journal of Applied Sciences Research, 9(3), 2170-2175. Retrieved from http://www. aensiweb.com/old/jasr/jasr/2013/21702175.pdf

Santos, D. F. L., Silva, B. L., Farinelli, J. B. M., Horita, K., Souza, C. A. F., \& Montoro, S. B. (2019). Economic viability of peanut production on leased land in the Jaboticabal region of São Paulo state, Brazil. Revista Agro@mbiente On-line, 13, 142-154. doi: 10.18 227/1982-8470ragro. v13i0.5342

Santos, F., Medina, P. F., Lourenção, A. L., Parisi, J. J. D., \& Godoy, I. J. (2013). Qualidade de sementes de amendoim armazenadas no estado de São Paulo. Bragantia, 72(3), 310-317. doi: 10.1590/brag.2013.029 
Santos, F., Medina, P. F., Lourenção, A. L., Parisi, J. J. D., \& Godoy, I. J. D. (2016a). Damage caused by fungi and insects to stored peanut seeds before processing. Bragantia, 75(2), 184-192. doi: 10.1590/ 1678-4499.182

Santos, R. R., Faroni, L. R. D., Cecon, P. R., Ferreira, A. P. S., \& Pereira, O. L. (2016b). Ozone as fungicide in rice grains. Revista Brasileira de Engenharia Agrícola e Ambiental, 20(3), 230-235. doi: 10.1590/1807-1929/ agriambi.v20n3p230-235
Shalmashi, A., \& Khodadadi, F. (2018). Ultrasound-assisted synthesis of biodiesel from peanut oil by using response surface methodology. Energy \& Environment, 30(10), 272-291. doi: 10. 1177/0958305X18790952

Silva, S. B., Luvielmo, M. M., Geyer, M. C., \& Prá, I. (2011). Potencialidades do uso do ozônio no processamento de alimentos. Semina: Ciências Agrárias, 32(2), 659-682. doi: 10.5433/1679-0359.2011v32n2p659 